\title{
THE COMBINED HEAT, ICE AND WATER BALANCE OF MaCALL GLACIER, ALASKA: A CONTRIBUTION TO THE INTERNATIONAL HYDROLOGICAL DECADE
}

\author{
By Gerd Wendeer and Nobuyoshi Ishikawa* \\ (Geophysical Institute, University of Alaska, Fairbanks, Alaska 9970 I, U.S.A.)
}

\begin{abstract}
The combined heat, ice and water balance was calculated for the McCall Glacier basin $\left(30.6 \mathrm{~km}^{2}\right)$ for a 36 day period in summer of 1971 . This period represents about half the ablation period in this region. The heat balance was measured by detailed observations over ice, and secondary stations were established over snow and moraine surfaces. The heat balances calculated for stations located respectively on ice and snow surfaces were assumed to be representative of all such surfaces. The moraine station was only used to obtain evaporation data for areas of the basin not covered by glacier (totalling about $70 \%$ ). Corrections were made to the radiative fluxes owing to screening of the surrounding mountains and the exposure of the glacier. The ice balance was calculated using 80 ablation/accumulation stakes and the discharge was measured with a water-level recorder, which was calibrated with a current meter. The precipitation was measured with seven rain gauges. Compared with the direct run-off measurements, the values calculated from the heat balance gave a value $5.5 \%$ higher, and the stake measurements a value $8.9 \%$ lower. This agreement is considered satisfactory and strengthens confidence in the methods employed in each of the three individual calculations.
\end{abstract}

RÉsumé. Le bilan combiné en chaleur, en glace et en eau du McCall Glacier, Alaska: une contribution a la Décennie Hydrologique Internationale. On a calculé le bilan combiné de chaleur, de glace et d'eau pour le bassin du McCall Glacier $\left(30,6 \mathrm{~km}^{2}\right)$ pour une période de 36 jours durant l'été $197 \mathrm{I}$. Cette période représente environ la moitié de la période d'ablation dans cette région. Le bilan thermique a été mesuré par des observations fines sur la glace, et des stations secondaires ont été installées sur la neige et sur la moraine. Les bilans thermiques calculés pour des stations situées respectivement sur la glace et sur la neige ont été considérés comme représentatifs de toutes les surfaces de ces catégories. La station sur moraine n'a été utilisée que pour obtenir des données sur l'évaporation pour les surfaces non englacées du bassin versant (au total environ $70 \%$ ). Des corrections aux flux rayonnés ont été apportées en fonction de l'écran des montagnes avoisinantes et de l'exposition du glacier. Le bilan de glace a été calculé par 80 balises d'accumulation-ablation et le débit a été mesuré avec un enregistreur de niveau étalonné avec un moulinet. Les précipitations étaient mesurées par 7 pluviomètres. Par comparaison avec les mesures directes d'écoulement, les valeurs calculées à partir du bilan thermique donnent un excédent de $5,5 \%$ et les balises un déficit de $8,9 \%$. Cette concordance est estimée satisfaisante et renforce la confiance dans les méthodes employées dans chacun des trois calculs.

Zusammenfassung. Der kombinierte Wärme-, Massen-, und Wasserhaushalt des McCall Glacier, Alaska: ein Beitrag zur Internationalen Hydrologischen Dekade. Der kombinierte Wärme-, Massen-, und Wasserhaushalt des Einzugsgebietes des McCall Glacier $\left(30,6 \mathrm{~km}^{2}\right)$ wurde für eine 36 tägige Periode im Sommer I $97 \mathrm{I}$ berechnet. Dieser Zeitraum stellt etwa die halbe Ablationsperiode für diese Gegend dar. Detaillierte Wärmebilanzmessungen wurden über Eis ausgetragen, und sekundäre Stationen wurden über Schnee und über einer Moräne aufgebaut. Die Wärmebilanz, die über Eis bzw. Schnee gemessen wurde, wurde für alle Eis- bzw. Schneeflächen als korrekt angenommen. Die Station auf der Moräne wurde nur zur Berechnung des Verdunstungswertes für den nichtvergletscherten Teil (etwa 70\%) des Einzugsgebietes verwendet. Die Strahlung, die der Gletscher erhält, wurde in Bezug auf Horizontabschirmung und Exposition korrigiert. Der Massenhaushalt wurde mit 8o Ablations-/Akkumulationspegeln berechnet, und der Abfluss wurde mit einem registrierenden Pegel gemessen, der mit einem Strömungsgeschwindigkeitmesser geeicht wurde. Der Niederschlag wurde mit 7 Niederschlagssammlern bestimmt. Ein Vergleich der direkten Abflussmessungen mit den berechneten Werten gab einen 5,5 prozentigen höheren Wert für die Wärmebilanz, und einen 8,9 prozentigen niedrigeren Wert für die Massenbilanz. Die Übereinstimmung kann als zufriedenstellend gelten, und stärkt das Vertrauen in den Methoden, die für die drei voneinander unabhängigen Berechnungen angewandt wurden.

\section{INTRODUCTION}

The McCall Glacier lies in the eastern and highest part of the Brooks Range (lat. $69^{\circ} \mathrm{I} 8^{\prime} \mathrm{N}$., long. $143^{\circ} 48^{\prime}$ W.) and the locality has been fully described elsewhere (e.g. Wendler and others, in press).

The present study estimates the combined heat, ice, and water balance of the McCall Glacier, which is one of the official goals of the International Hydrological Decade (I.H.D. I966). To the authors' knowledge, this is the first time, that such a comparison has been

* On leave from the Institute of Low Temperature Science, University of Hokkaido, Sapporo. 
attempted for a whole glacier. Previously, some investigations of the combined ice and water balance have been carried out (e.g. Meier and others, I97I ; Wendler and others, in press), and heat balance studies at one point have been compared with the run-off and ablation of small controlled area on glaciers (Lang, I968; Derikx, in press; Wendler and Ishikawa, I973[a]).

\section{INSTRUMENTATION AND PERIOD OF OBSERVATION}

The instrumentation has been described previously (Wendler and Weller, 1974) and hence this description is very brief. A first-class micrometeorological station was established at I $740 \mathrm{~m}$ on the glacier tongue (see Fig. I). At this site, profile measurements were made at four heights of temperature, humidity, and wind, and short- and long-wave incoming and

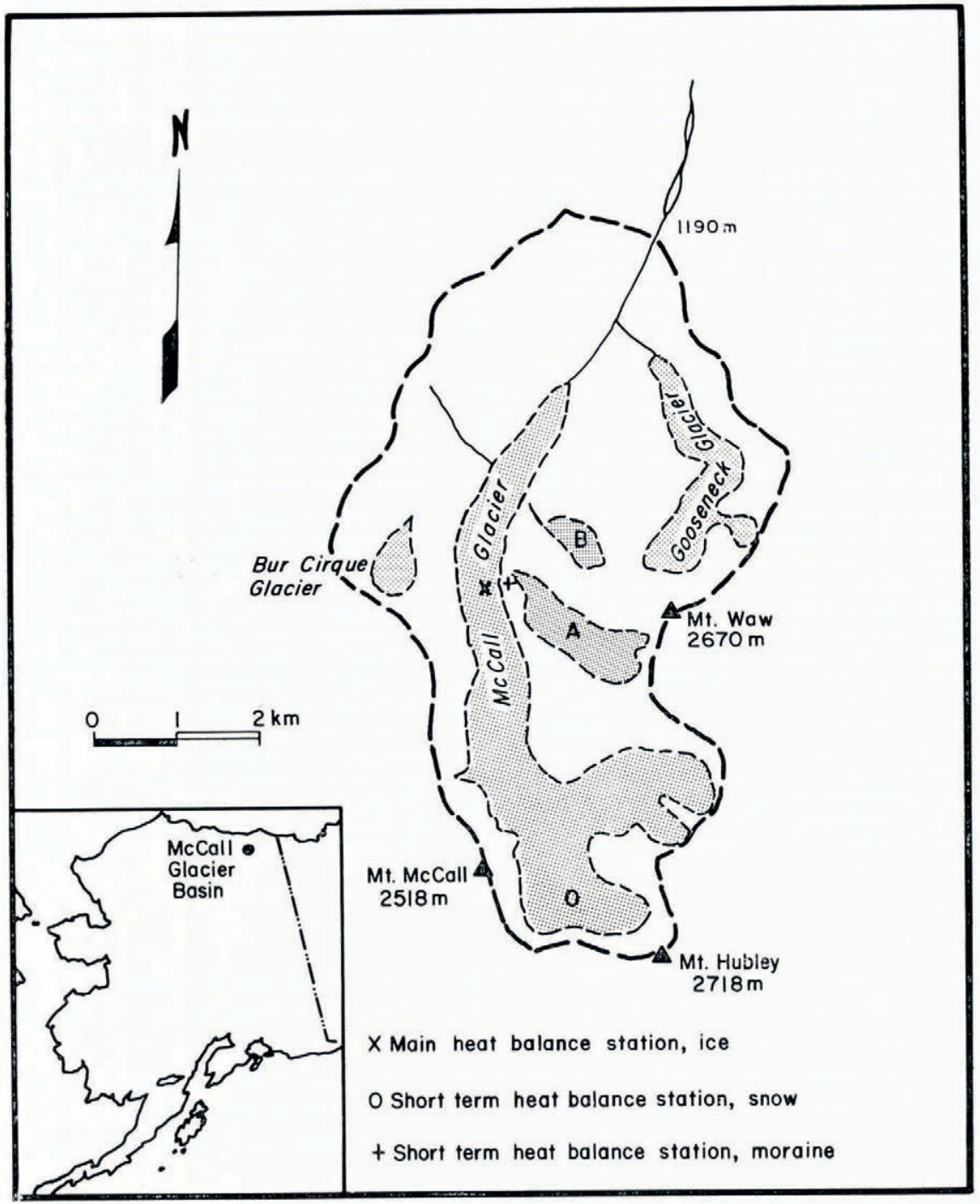

Fig. I. Locality map of the McCall Glacier basin. 
outgoing radiation fluxes were measured. The ice temperatures were recorded down to a depth of ro $\mathrm{m}$. A second-class station was established in the lowest of the three firn basins (Fig. I) at an altitude of $2100 \mathrm{~m}$. For part of the time, temperature and humidity were recorded at two levels, but for the remainder at only one. Wind velocity was also recorded, and spot measurements of the snow temperature, snow density and albedo were carried out. The run-off was measured with a water-level recorder at the McCall Creek, about $2 \mathrm{~km}$ down from the terminus of the glacier, and was calibrated with a current meter. Ice ablation was measured with ablation stakes, and for daily mean values, 20 micro-stakes were installed at the main observational site. The observations were commenced in the spring of 1969 , and were carried out for the four summers until 1972. However, owing to difficulties with the micrometeorological equipment as well as with the water-level recorder (the stream changed its course several times) periods with good data from all instrumentation are rare. One of these is the period of 17 June to 22 July 197 I, a 36 day period, for which the combined heat, ice and water balance is calculated. The calculation was limited to this short period-it represents nearly half of the ablation period-as good run-off measurements were then available. Before I 7 June, aufeis in the McCall Creek (Trabant and others, in press) prevented run-off measurements and on 23 July 1973 the McCall Creek changed its course.

\section{Meteorological gonditions during the observation period}

The observation period was within the main ablation period, which lasts for $2-3$ months on the McCall Glacier. The mean and extreme climatological conditions at the principal station can be seen in Table I; the mean temperature $\left(3.2^{\circ} \mathrm{C}\right)$ is a typical value for the warmest month of the year so far as can be estimated from the limited amount of data (Orvig, I96r; Wendler and Weller, 1974). An absolute range of more than 20 deg was observed, with $12.0^{\circ} \mathrm{C}$ as the highest temperature and a minimum of nearly $-10^{\circ} \mathrm{C}$. There is no period of the year in which freezing does not occur on McCall Glacier. The water vapor pressure is in the mean $\left(6.17\right.$ mbar) very near to the saturation vapor pressure of water at $0^{\circ} \mathrm{C}$ and has an absolute range of more than 6 mbar.

\begin{tabular}{|c|c|c|}
\hline $\begin{array}{l}\text { Air temperature (1 m) } \\
\quad\left({ }^{\circ} \mathrm{C}\right)\end{array}$ & $\begin{array}{l}\text { Absolute maximum } \\
\text { Absolute minimum } \\
\text { Mean }\end{array}$ & $\begin{array}{r}12.0 \\
-9.7 \\
3.2\end{array}$ \\
\hline $\begin{array}{l}\text { Water vapor pressure (I m) } \\
(\text { mbar })\end{array}$ & $\begin{array}{l}\text { Absolute maximum } \\
\text { Absolute minimum } \\
\text { Mean }\end{array}$ & $\begin{array}{l}9.07 \\
2.57 \\
6.17\end{array}$ \\
\hline $\begin{array}{l}\text { Wind speed (at } 2 \mathrm{~m}) \\
\left(\mathrm{m} \mathrm{s}^{-1}\right)\end{array}$ & $\begin{array}{l}\text { Absolute maximum } \\
\text { Absolute minimum } \\
\text { Mean }\end{array}$ & $\begin{array}{l}7.4 \\
0.4 \\
3.0\end{array}$ \\
\hline $\begin{array}{l}\text { Cloudiness } \\
\text { (tenths) }\end{array}$ & $\begin{array}{l}\text { Absolute maximum } \\
\text { Absolute minimum } \\
\text { Mean }\end{array}$ & $\begin{array}{r}\text { I0.0 } \\
0.0 \\
6.2\end{array}$ \\
\hline
\end{tabular}

The extremes represent hourly values.

The wind speed was never very high, as no strong storm occurred during the observation period. Calm conditions lasting one hour or more were not observed, as a glacier wind blowing down the ice slope is nearly always present. The mean cloudiness is 6.2 tenths, which is lower than values found at Barter Island where the longer term mean for June and July is 7.9 tenths (Searby, 1968). This is to be expected, as the McCall Glacier is frequently above the level of the stratus cloud which is so frequently found over the Arctic Ocean and the adjacent north slope in summer. 
Two cold spells occurred during the observation period, one at the end of June, and the other around the middle of July. The daily mean and extreme values of temperature, water vapor and wind speed are shown in Figure 2 and the mean diurnal variation of the climatic data are given in Table II. One can see that, on the average, freezing occurs daily, even though the sun never sets at this time of the year.
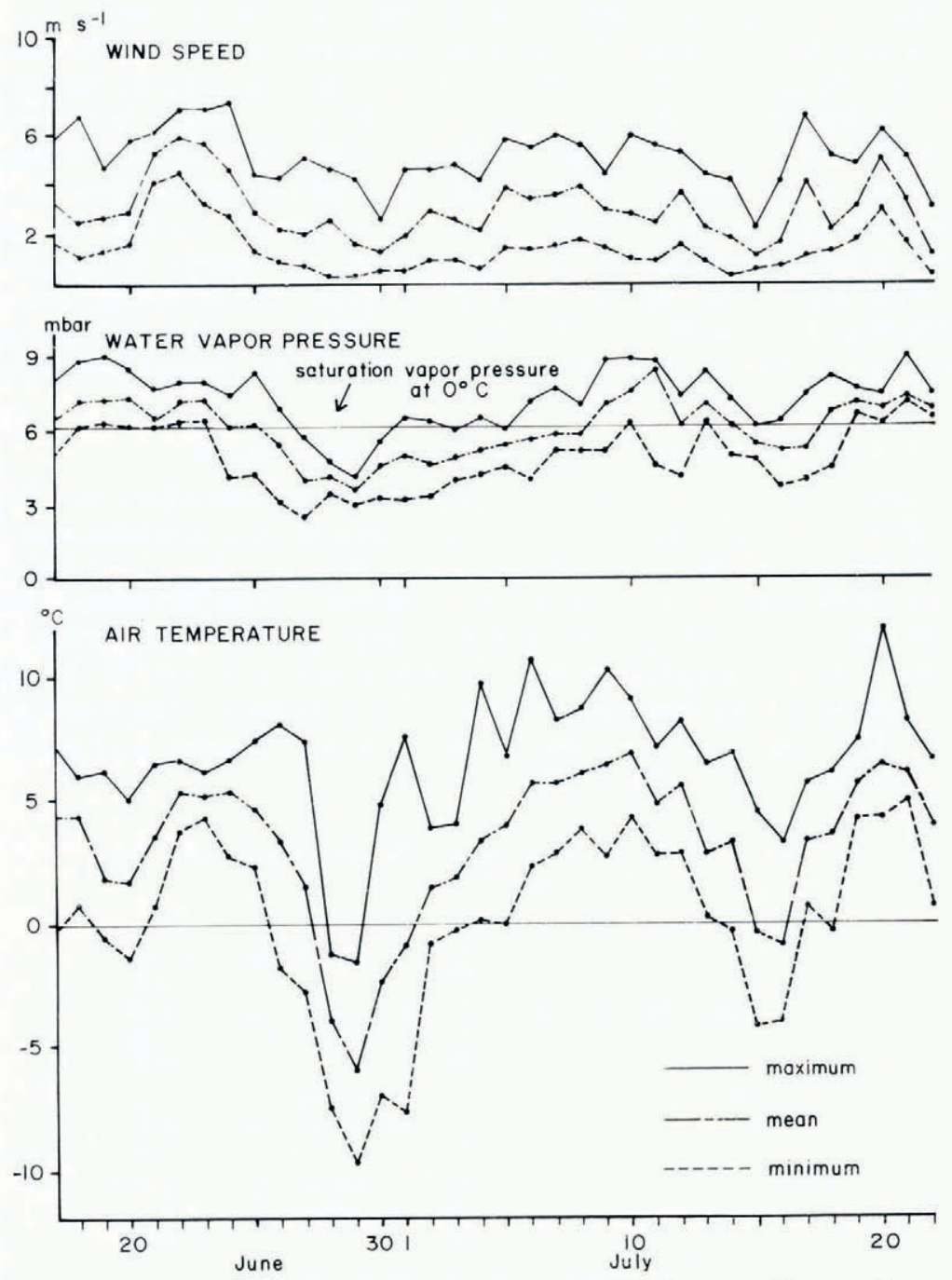

Fig. 2. Daily mean and extreme meteorological elements, McCall Glacier, 17 June-22 July 1971.

Table II. Mean diurnal variations in meteorological conditions, McCall Glacier, i 7 June-22 July 197I

$\begin{array}{lccc} & \begin{array}{c}\text { Air temperature } \\ { }^{\circ} \mathrm{C}\end{array} & \begin{array}{c}\text { Water vapor pressure } \\ \text { mbar }\end{array} & \begin{array}{c}\text { Wind speed } \\ \mathrm{m} \mathrm{s}^{-1}\end{array} \\ \text { Mean maximum } & 6.6 & 7.37 & 5.1 \\ \text { Mean minimum } & -0.9 & 4.92 & 1.5 \\ \text { Mean range } & 7.5 & 2.45 & 3.6\end{array}$




\section{Some topographic characteristics of MaCall Glacier basin}

The McCall Glacier basin has a size of $30.6 \mathrm{~km}^{2}$ and stretches from the run-off site at I $\mathrm{I} 90 \mathrm{~m}$ to Mt Hubley at $27 \mathrm{I} 8 \mathrm{~m}$ (Fig. I). Some $9 . \mathrm{rm}^{2}$ or $30 \%$ of the basin is glacier covered, the McCall Glacier $\left(6.22 \mathrm{~km}^{2}\right)$ forming the major part. In addition, the Gooseneck Glacier $\left(\mathrm{I} .48 \mathrm{~km}^{2}\right)$, glacier A $\left(0.89 \mathrm{~km}^{2}\right)$, Bur Cirque Glacier $\left(0.33 \mathrm{~km}^{2}\right)$ and glacier B

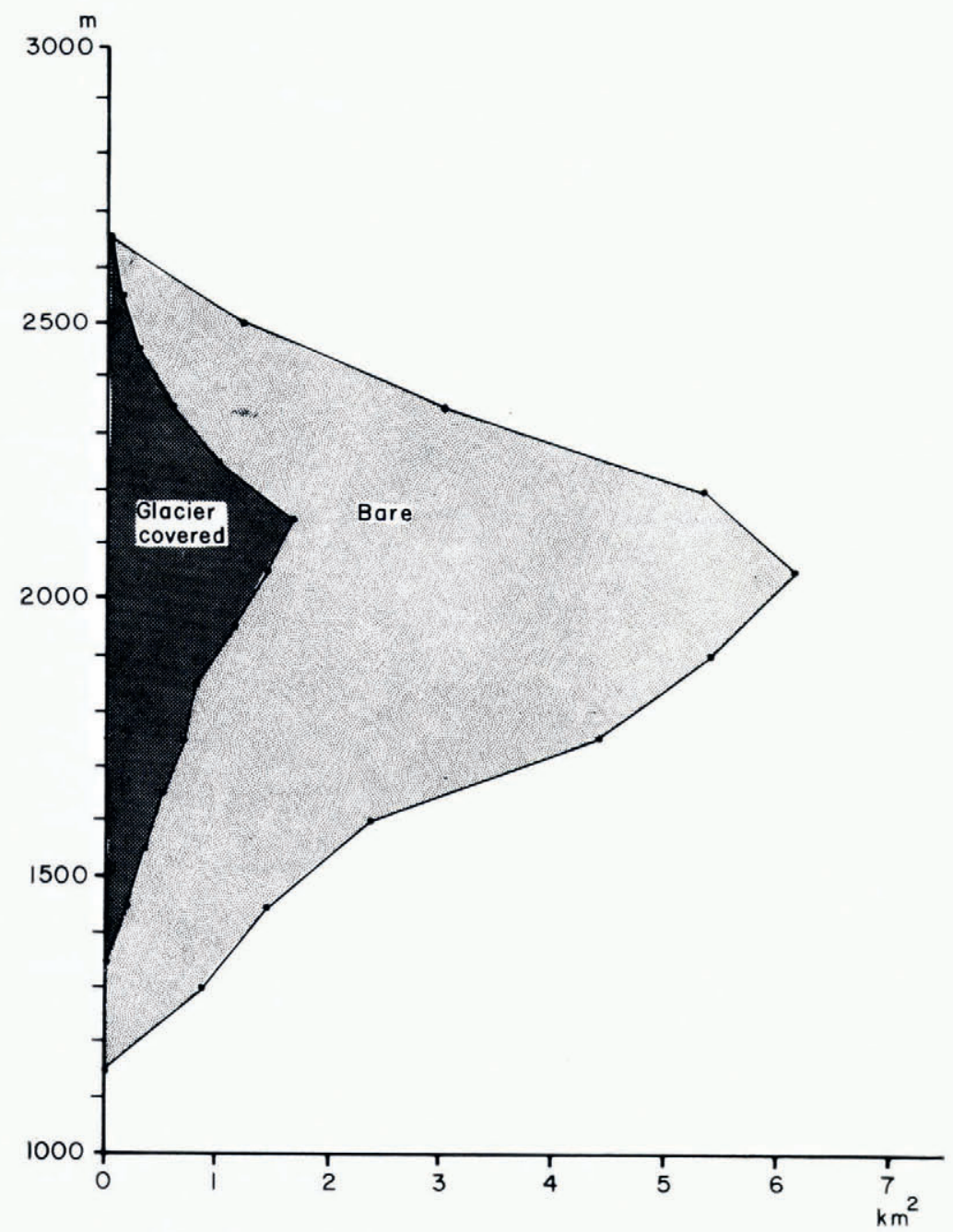

Fig. 3. Altitude distributions of the total and glacier-covered area in the McCall Glacier basin in Ioo $m$ steps.

$\left(0.25 \mathrm{~km}^{2}\right)$ are located in the basin, glaciers A and B being glaciers with no officially recognized names. The altitude-area relationship for glacier-covered and total areas are given in Figure 3 . One can see that for the whole basin the greatest area lies between $2000 \mathrm{~m}$ and $2100 \mathrm{~m}$, while for the glacier-covered area this is $100 \mathrm{~m}$ higher. The altitude span of the glaciers and the relative distribution of area as a function of height are given in Figure 4, the McCall Glacier having the greatest altitude span. 


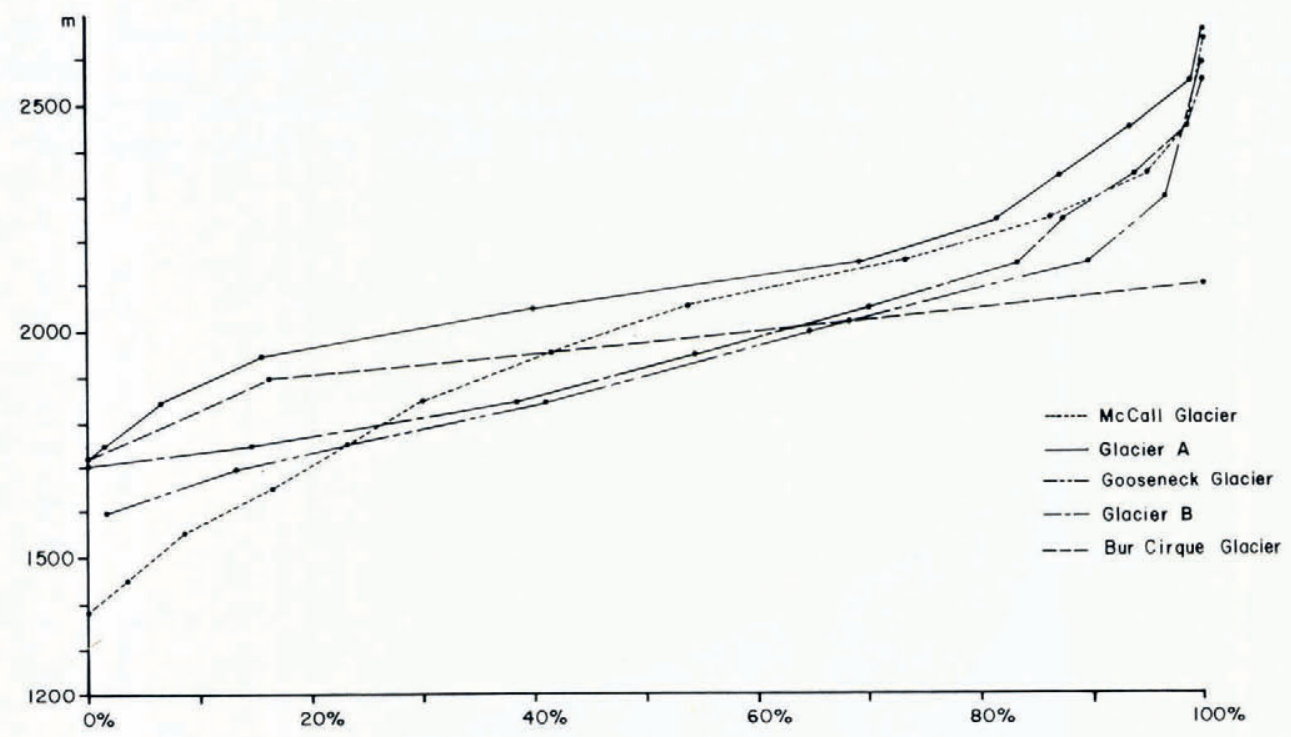

Fig. 4. Relative altitude distributions of the five glaciers in the McCall Glacier basin.

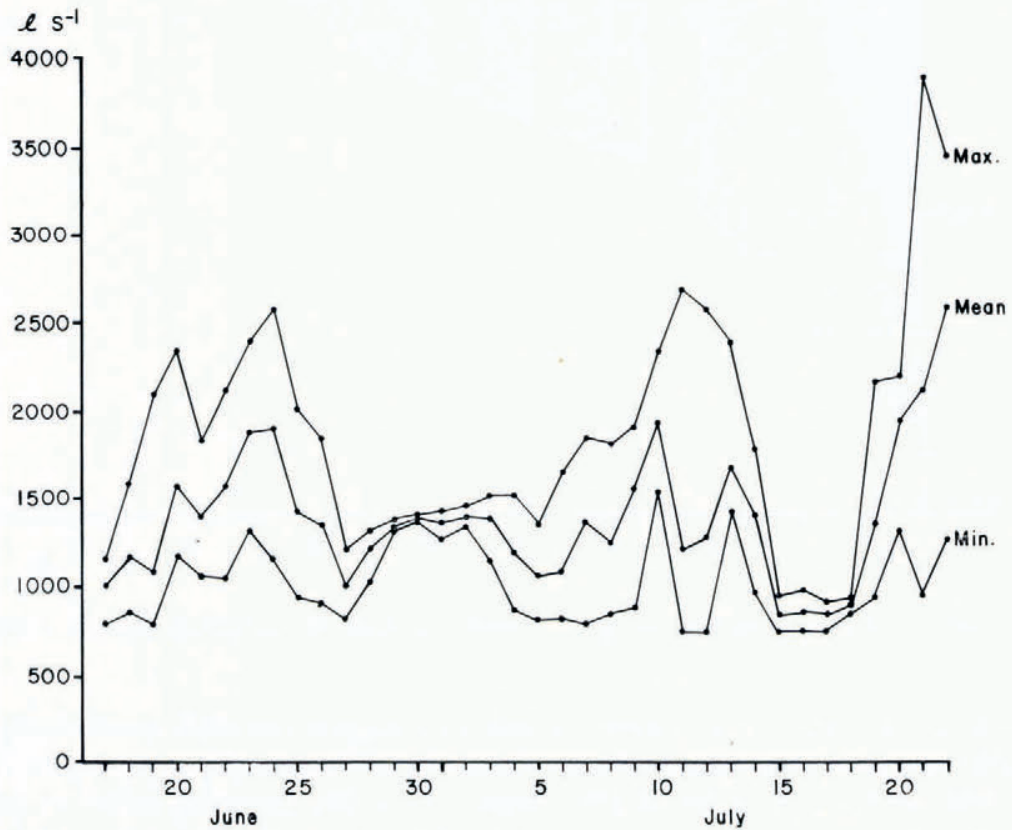

Fig. 5. Daily mean and extreme values of the discharge, McCall Creek, 17 June-22 July 1971. 


\section{The Results of the RUN-OFF measurements}

The discharge was measured with a Stevens water-level recorder, and calibration measurements were carried out with an Ott current meter. The calibration curve and the difficulties have been described elsewhere (Wendler and others, in press).

Daily mean and extreme values of the discharge are given in Figure 5. The maximum was found on $2 \mathrm{I}$ July $197 \mathrm{I}$ with nearly $4000 \mathrm{l} \mathrm{s}^{-1}$; the discharge never went below $750 \mathrm{l} \mathrm{s}^{-1}$ and a mean value of $13901 \mathrm{~s}^{-1}$ was measured for the 36 day period. A comparison of the three methods of calculating the run-off cannot be carried out on daily basis owing to the basin's storage capacity for liquid water and the time lag in the run-off. Hence, a comparison was attempted for five-day periods as well as for the whole observation period. Therefore, the mean and extreme values are given for five-day periods in Table III. One can see that for the time of the two cold spells (Fig. 2) the run-off is reduced.

TAble III. Mean and extreme values of Run-off for five-Day periods, McCall Glacier, I 7 JUNE-22 JULY 197 I

$\begin{array}{lcccr}\begin{array}{c}\text { Amount } \\ \times \mathrm{IO}^{3} \mathrm{~m}^{3}\end{array} & \begin{array}{c}\text { Daily mean } \\ \times \mathrm{IO}^{3} \mathrm{~m}^{3} \mathrm{~d}^{-1}\end{array} & \begin{array}{c}\text { Daily maximum } \\ \times \mathrm{IO}^{3} \mathrm{~m}^{3} \mathrm{~d}^{-1}\end{array} & \begin{array}{c}\text { Daily minimum } \\ \times \mathrm{IO}^{3} \mathrm{~m}^{3} \mathrm{~d}^{-1}\end{array} \\ \text { 1 7-2 I June } & 537 & 107 & 136 & 87 \\ \text { 22-26 June } & 705 & 14 \mathrm{I} & 166 & 1 \mathrm{1} 6 \\ \text { 27 June-1 July } & 545 & 109 & 120 & 87 \\ \text { 2-6 July } & 529 & 106 & 121 & 92 \\ \text { 7-1 I July } & 633 & 127 & 168 & 104 \\ \text { 1 2-16 July } & 525 & 105 & 146 & 73 \\ \text { 17-22 July } & 848 & 14 \mathrm{I} & 224 & 74 \\ \text { Total period } & 4322 & 120 & 224 & 73\end{array}$

\section{Ablation from stake measurements}

Eighty ablation/accumulation stakes were sited on the McCall Glacier, or 13 per $\mathrm{km}^{2}$. It may be noted that io per $\mathrm{km}^{2}$ were found sufficient by Hoinkes (1964) to obtain good values for the mass balance of a glacier of simple topography. The amount of ablation was calculated for each point, and an ablation map constructed (Fig. 6). It can be seen that the maximum amount at the snout of the glacier is in excess of $120 \mathrm{~cm}$ water equivalent for the 36 day period, which is more than half of the annual amount (Trabant and others, in press). With increasing height, the amount of ablation decreases, and in the higher firn basin less than Io $\mathrm{cm}$ water equivalent of surface ablation occurred. Difficulties occur if one wants to compare ice ablation with run-off, as part of the surface ablation refreezes in the deeper layers. As the annual mean temperature is far below the freezing point (about $-12^{\circ} \mathrm{C}$ was found at $\mathrm{I} 740 \mathrm{~m}$ altitude), this is of great importance. By using temperature measurements in the firn basins during different times of the ablation season, the amount of water which refroze could be estimated (Trabant and others, in press). We found a value of $80 \%$ for the mean of the firn basin in this 36 day period. Such a high percentage occurs because the observational period was relatively early in the season, at a time when the firn has temperatures far below freezing. For the smaller glaciers in the McCall Creek Basin, no or few direct measurements of the ablation were carried out. Using the amount of ablation as a function of height from the McCall Glacier (Fig. 7) and knowing the altitude distribution of the other smaller glaciers (Fig. 4), the amount of snow and ice melt could be estimated assuming that the ablation is a function only of altitude. To obtain values for five-day intervals, the values of 20 microstakes, which were located near the main observation site, were utilized, as all ablation stakes were not read every five days. The results, which were found, are given in Table IV.

If the ice balance is to be compared with the water balance, the precipitation and the evaporation in the area have also to be taken into account. Precipitation gauges were located 


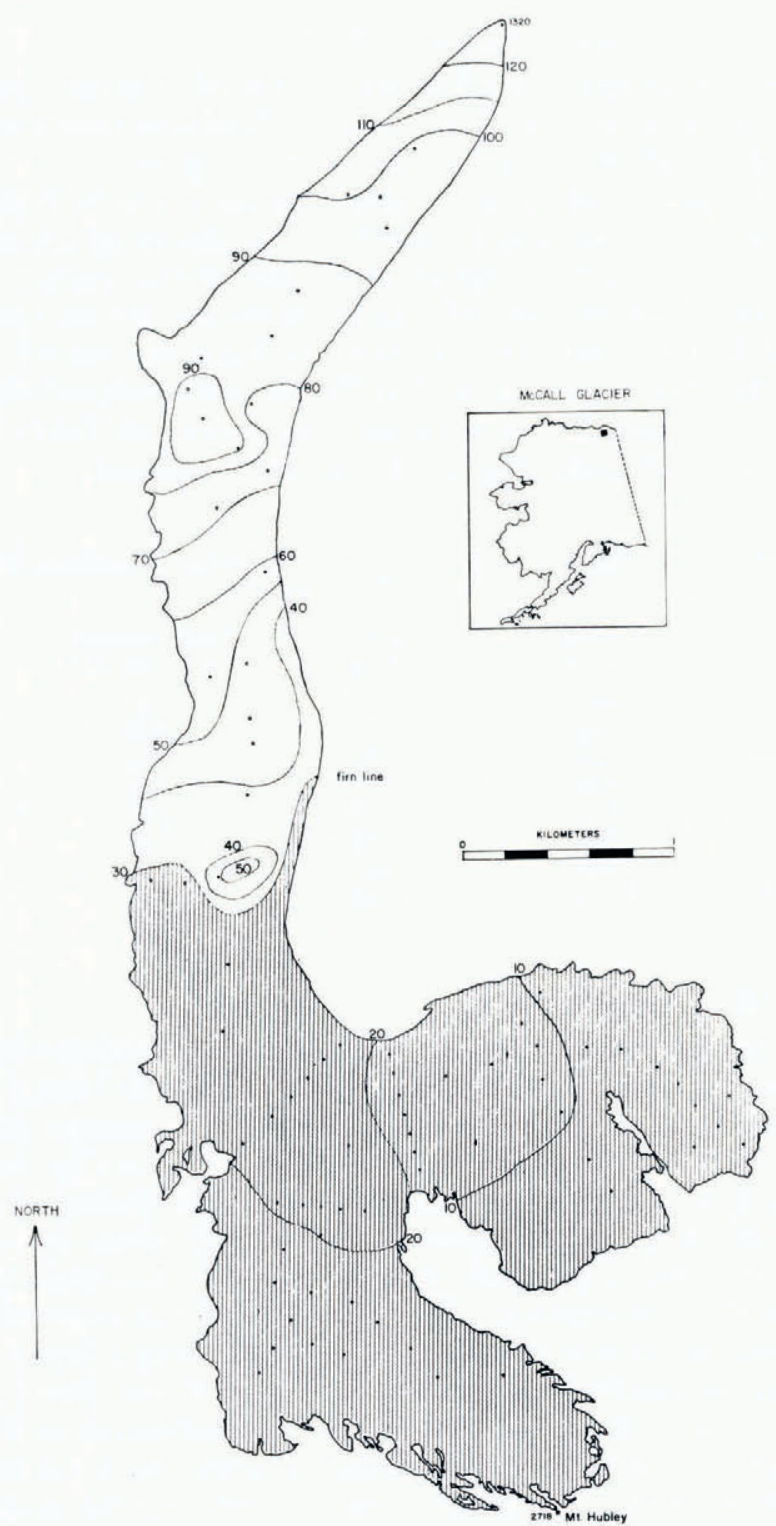

Fig. 6. Ablation in $\mathrm{cm}$ water equivalent of McCall Glacier, 17 June-22 July 1971 . The points represent stake locations.

at seven points in the McCall Creek Basin. The main station, which had the only recording rain gauge, was fairly representative. It was found that on the average a $6.9 \%$ higher value would be representative of the whole basin.

The evaporation was measured over a moraine at I $740 \mathrm{~m}$ for an eleven day period, which was within the $3^{6}$ day period of this study (Wendler and Ishikawa, 1973[b]). A mean daily value for the evaporation of $1.05 \mathrm{~mm}$ water was found. This value was assumed to be representative of all areas not glacier covered and for the whole period.

A comparison between the water and ice balance is now possible. This is described in section 8 . 


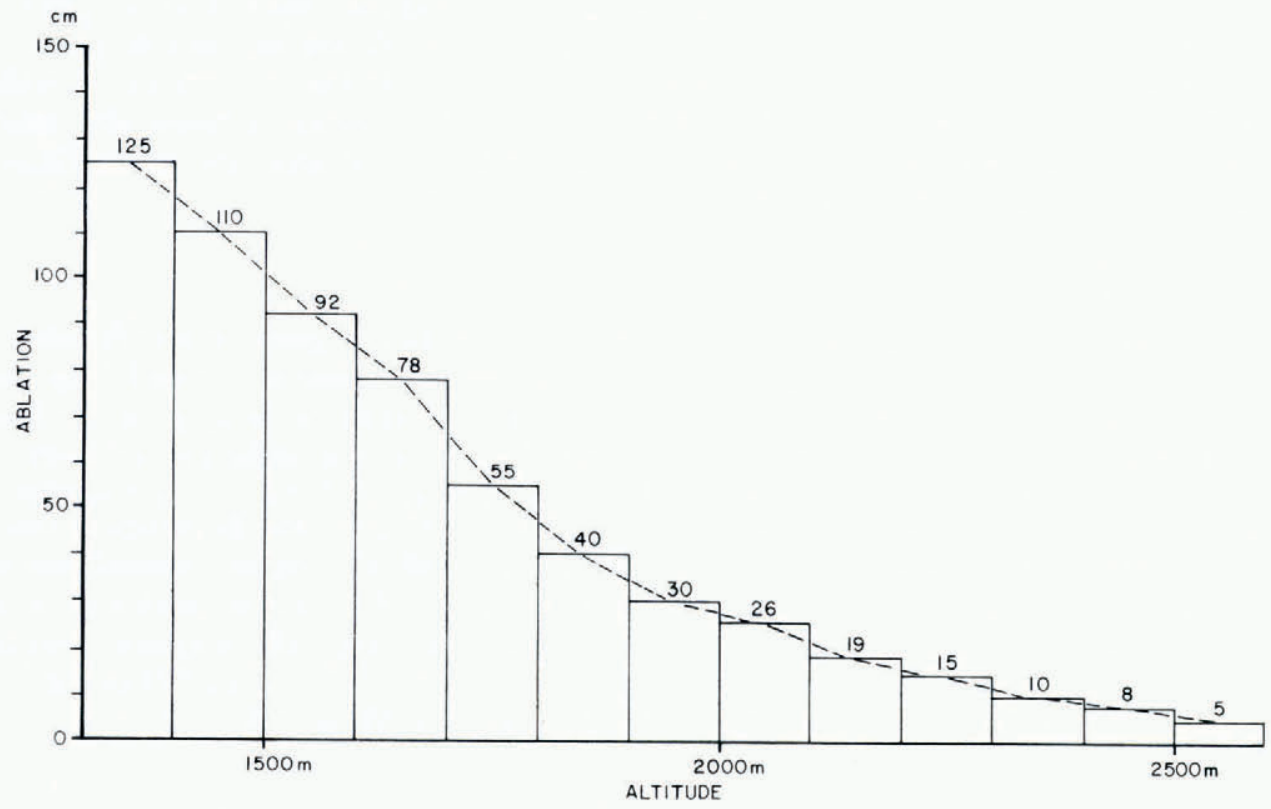

Fig. 7. Ablation as function of height, McCall Glacier, 17 June-22 fuly 1971.

Table IV. Amount of ablation of the glaciers in the McCall Glacier Basin for five-day periods

Period

17-21 June

22-26 June

27 June-1 July

2-6 July

7-1 I July

1 2-16 July

1 7-22 July

Total period

Ice melt
$\times 10^{3} \mathrm{~m}^{3}$
421
539
72
217
436
129
275
2089

7. Heat balance studies of the whole basin

The heat balance can be calulated for the surface using profile measurements of the meteorological data (e.g. Albrecht, I940; Munn, I966). The following terms were considered in the heat balance equation:

(1) radiation balance, short-wave $R_{\mathrm{s}}$,

(2) radiation balance, long-wave $R_{1}$,

(3) sensible heat flux $S$,

(4) latent heat flux $L$,

(5) heat flux in the ice or snow $C$,

(6) snow or ice melt $M$.

The sum of all fluxes is zero, if no advection takes place:

$$
R_{\mathrm{s}}+R_{\mathrm{l}}+S+L+C+M=\text { o. }
$$

Fluxes towards the surface are considered as positive, and those away from the surface as negative. 
Heat-balance studies on glaciers have been carried out for more than 20 years (e.g. Hoinkes, 1953). However, these measurements were done only for one specific point. The extension from one point over a whole glacier is difficult and has not been attempted, with the possible exception of Hoinkes and Wendler (1968). These authors extended the radiation terms which gave the greatest contribution to the melting of the snow and ice in Hintereisferner, Austria, in the summer of $195^{8}$.

\section{A. Radiation balance}

As the heat balance of 1970 has been discussed previously in great detail (Wendler and Weller, 1974), this discussion is brief. The mean and extreme radiative values for the micrometeorological site are given in Table $\mathrm{V}$ for the period 17 June to 22 July $197 \mathrm{I}$. A mean value of $478 \mathrm{Ly} \mathrm{d}^{-1}\left(20.0 \mathrm{MJ} \mathrm{m}^{-2} \mathrm{~d}^{-1}\right)$ was observed for the global radiation, of which $39 \%$ was reflected. The albedo had a great variability and a range from 83 to $20 \%$ was observed. The albedo, of course depends on the surface conditions and new snow fall tends to raise the albedo substantially. Therefore, the daily mean values of albedo and the snowfall are given in Figure 8. One can see that the highest values are observed with new snow and, further, that the albedo drops when the snow has melted on the glacier. The long-wave radiation balance (Table V) is negative, and a mean value of $-165 \mathrm{Ly} \mathrm{d}^{-1}\left(-6.9 \mathrm{MJ} \mathrm{m}^{-2} \mathrm{~d}^{-1}\right)$ was observed, resulting in an all-wave balance of $134 \mathrm{Ly} \mathrm{d}^{-1}\left(5.6 \mathrm{MJ} \mathrm{m}^{-2} \mathrm{~d}^{-1}\right)$.

Table V. Measured radiative fluxes, McCall Glacier, 17 June-22 July 197 I

Short-wave incoming Short-wave outgoing Short-wave balance Long-wave balance All wave balance Albedo

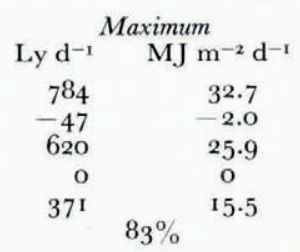

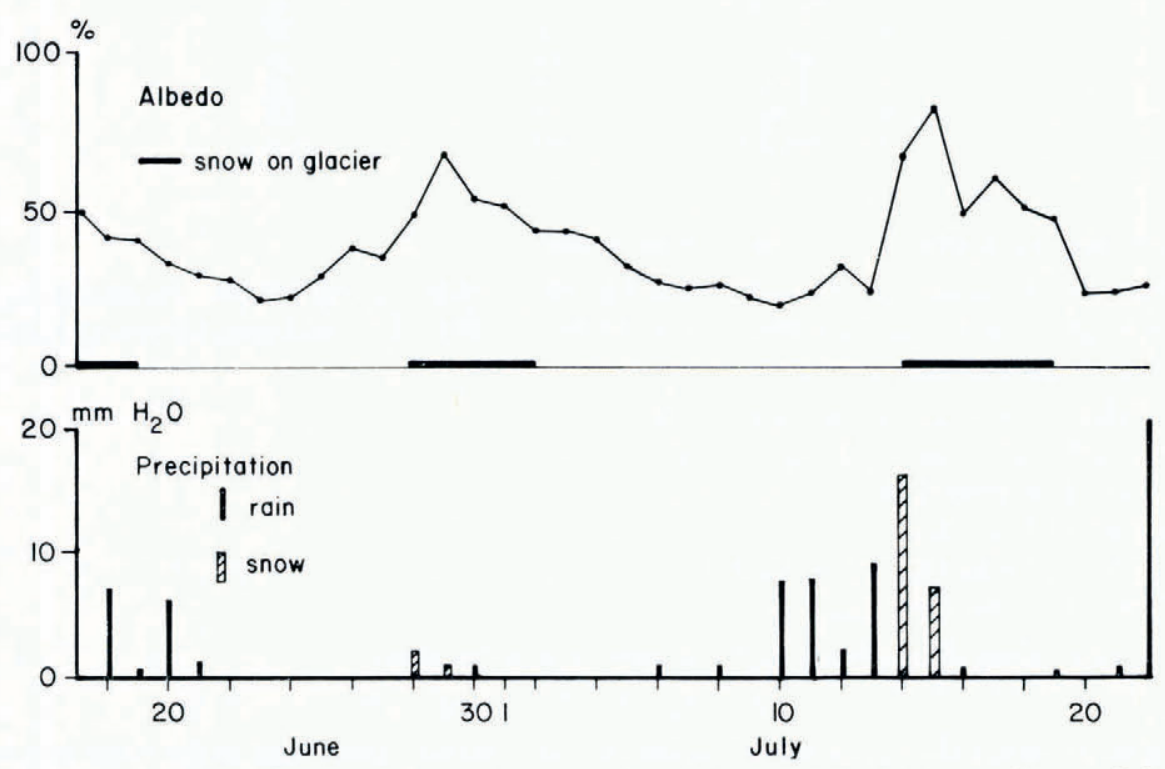

Fig. 8. Mean daily albedos, surface conditions and the amounts of precipitation, McCall Glacier, I7 June-22 July 1971 . 
It is a difficult problem to extend the radiation balance which is measured at one point over the whole glacier surface. There are four factors, which influence the radiation balance:

(I) A glacier is normally not horizontal, however, the radiative fluxes are measured on a horizontal surface. Corrections have to be made for the slope angle and direction of the glacier.

(2) The mountains which surround the glacier have a screening effect on the direct solar radiation, by which a glacier receives substantially less radiation than an area with a flat horizon.

(3) The albedo of the glacier is not uniform. Great differences are found between snow and ice.

(4) The surface temperature and hence the outgoing long-wave radiation varies over the glacier.

Further, the incoming short- and long-wave radiation are to some extent dependent on the altitude. However, as this dependence is not important within a relatively small glacier basin, it was disregarded.

The effects of points I and 2 have been treated in detail elsewhere, (Wendler and Ishikawa, 1974). At the micrometeorological site, the calculated amount of incoming solar radiation lost owing to the screening of the mountains at this specific location was added to the measure of value of the global radiation. To do this one has to know the percentage of the direct solar radiation in total global radiation. This could be obtained from tables given by Kondratyev (1969) using the observed cloudiness. From these values, the losses owing to the exposure and the screening effect of the mountains for the glacier as a whole were deduced (Wendler and Ishikawa, 1974). Again, the direct solar radiation as a percentage of the global radiation was considered, as the sky radiation was assumed to be constant for all surfaces. This assumption is reasonable, as the sky radiation which is lost due to the screening effect of the mountains is normally compensated by the reflected radiation from the surrounding slopes (Turner, I $96 \mathrm{I}$ ).

Several measurements of the albedo of the snow resulted in a mean value of $59 \%$. This value was assumed to be representative of the entire snow surface, while for the whole ice surface the value measured at the micrometeorological site was used. However, when the albedo at the micrometeorological site was higher than $59 \%$ (which occurred after new snowfalls), the measured value was assumed as representative of the entire glacier surface.

The average air temperature was found to be the same within $0 . \mathrm{I}^{\circ} \mathrm{C}$ for the two stations ( $1740 \mathrm{~m}$ and $2 \mathrm{I} 40 \mathrm{~m}$ ). Therefore it was assumed that the surface temperatures and hence the outgoing long-wave radiation, which was measured at the micrometeorological site was representative for the whole glacier. Thus, corrected radiative fluxes for the snow and ice surfaces of the McCall Glacier as a whole could be calculated. The mean and extreme values are given in Table VI.

Table VI. Corrected radiative fluxes over ice and snow, McCall Glacier, i 7 June-22 July 1971

\begin{tabular}{|c|c|c|c|c|c|c|c|c|c|}
\hline & \multicolumn{3}{|c|}{ Short-wave balance } & \multirow{2}{*}{\multicolumn{2}{|c|}{$\begin{array}{c}\text { Long-wave balance } \\
\text { Ice }(=\text { Snow })\end{array}$}} & \multicolumn{4}{|c|}{ All-wave balance } \\
\hline & Ice & & Snow & & & & Ice & & Snow \\
\hline Ly d $^{-1}$ & $M J m^{-2} d^{-1}$ & Ly d $^{-1}$ & $M J m^{-2} d^{-1}$ & $\mathrm{Ly} \mathrm{d}^{-\mathrm{I}}$ & $M J m^{-2} d^{-1}$ & $\operatorname{Lyd~d~}^{-1}$ & $\mathrm{MJ} \mathrm{m}^{-2} \mathrm{~d}^{-1}$ & Ly d $^{-1}$ & $\mathrm{MJ} \mathrm{m}^{-2} \mathrm{~d}^{-1}$ \\
\hline Mean & 13.8 & 200 & 8.3 & -166 & -6.9 & I 66.2 & 6.9 & 34 & I. 4 \\
\hline Maximum 58I & 24.2 & $33^{6}$ & 14.0 & $-\mathbf{I}$ & -0.05 & 330.7 & 13.8 & 149 & 6.2 \\
\hline Minimum 60 & 2.5 & 60 & 2.5 & -294 & -12.3 & $-\operatorname{sog} .6$ & -4.6 & -109.6 & -4.6 \\
\hline
\end{tabular}

\section{B. The eddy fluxes}

The sensible and latent heat fluxes were calculated for the two stations over ice and snow using relationships established by Lettau (1939, 1949) and Prandtl (1956). As these measurements have been described in detail previously (Wendler and Ishikawa, I973[a]; Wendler and Weller, I974), only the results are given (Table VII). One can see that the fluxes are smaller 
over the snow surface, which was caused by less wind. The wind speed was in the mean $43 \%$ higher at the micrometeorological site than over the snow station as the katabatic wind was much more developed on the glacier tongue where the micrometeorological site was located than in the firn basin.

Table VII. Sensible and latent heat fluxes over ice and snow, McCall Glacier, 17 June-22 July 1971

\begin{tabular}{|c|c|c|c|c|c|c|c|c|}
\hline & \multicolumn{4}{|c|}{ Sensible } & \multicolumn{4}{|c|}{ Latent } \\
\hline & Lyd $^{-1}$ & $\begin{array}{l}\text { Ice } \\
\mathrm{MJ} \mathrm{m}^{-2} \mathrm{~d}^{-1}\end{array}$ & Lyd $^{-1}$ & $\begin{array}{l}\text { Snow } \\
\text { MJ m-2 } \mathrm{d}^{-1}\end{array}$ & Ly d $^{-1}$ & $\begin{array}{l}I c e \\
\mathrm{MJ} \mathrm{m}^{-2} \mathrm{~d}^{-1}\end{array}$ & Ly d $^{-1}$ & $\begin{array}{l}\text { Snow } \\
\mathrm{MJ} \mathrm{m}^{-2} \mathrm{~d}^{-1}\end{array}$ \\
\hline Mean & $9^{2}$ & 3.9 & 53 & 2.2 & 12 & 0.5 & 3 & 0.1 \\
\hline Maximum & 270 & 11.2 & 90 & 3.8 & 76 & 3.2 & $4^{6}$ & 1.9 \\
\hline Minimum & -19 & -0.8 & -18 & -0.8 & -39 & -1.6 & -39 & $-\mathrm{r} .6$ \\
\hline
\end{tabular}

\section{Heat flux in ice and snow, and ablation of ice and snow}

At the micrometeorological site, the ice temperatures were measured continuously down to a depth of ro $\mathrm{m}$. A mean amount of $\mathrm{i} 6 \mathrm{Ly} \mathrm{d}^{-1}\left(0.7 \mathrm{MJ} \mathrm{m}^{-2} \mathrm{~d}^{-1}\right)$ was calculated for conduction, which was used to warm the ice. For the snow site, only spot measurements of the temperature profile were available. For conduction in the snow a small value of $1.3 \mathrm{Ly} \mathrm{d}^{-1}$ $\left(0.05 \mathrm{MJ} \mathrm{m}^{-2} \mathrm{~d}^{-1}\right.$ ) was found; this value is very small because snow is a good insulator, and furthermore, at the end of the observation period, the upper layer of the snow was isothermal and hence no heat could be transported by conduction.

The ice ablation was measured at the ice site with 20 small ablation stakes twice daily. A mean value of $32 \mathrm{~mm}$ water equivalent was found per day. For the snow site, where the ablation was measured with one ablation stake less frequently, a mean value of I I mm water equivalent was observed. Details of these measurements have been described previously (Wendler and Ishikawa, 1973[b]).

\section{The heat balance as a whole over ice and snow}

The components of the heat balance are given in Table VIII and Figure 9. One can see that for both sites the solar radiation is the most important heat source, even more so over ice than snow. This result, which is to be expected, was found previously by many investigators (e.g. LaChapelle, I959; Hoinkes, I955; Streten and Wendler, 1968). The second most important heat flux is the sensible heat flux, which means that the air warmed the surface. Condensation overcompensated the evaporation, and therefore a positive latent heat flux was observed. However, this might not be typical, as the opposite result was found in a study of longer duration during the previous summer (Wendler and Weller, r974). The incoming energy was balanced by the energy sinks, viz. melting, the long-wave radiation balance and, to a much lesser extent, the heating of the ice and snow.

Table VIII. Components of the heat balance over ice and snow, McCall Glacier, 17 June-22 July 1971

\begin{tabular}{|c|c|c|c|c|c|c|c|c|c|c|}
\hline \multirow{3}{*}{ Components } & \multicolumn{4}{|c|}{ Total period } & \multicolumn{4}{|c|}{ Daily average } & \multicolumn{2}{|c|}{ Percentages } \\
\hline & I & ce & Sno & & & Ice & & Snow & Ice & Snow \\
\hline & Ly & $\mathrm{MJ} \mathrm{m}^{-2}$ & Ly & $\mathrm{MJ} \mathrm{m}^{-2}$ & $\operatorname{Lyd}^{-1}$ & $\mathrm{MJ} \mathrm{m}^{-2} \mathrm{~d}^{-1}$ & Ly d $^{-1}$ & $M J m^{-2} d^{-1}$ & & \\
\hline $\begin{array}{c}\text { Short-wave } \\
\text { balance }\end{array}$ & I I $95^{2}$ & $49^{8.4}$ & 7207 & 300.5 & $33^{2}$ & I 3.8 & 200 & 8.3 & 76.1 & 78.2 \\
\hline $\begin{array}{c}\text { Long-wave } \\
\text { balance }\end{array}$ & $-59^{67}$ & -248.8 & $-59 \epsilon_{7}$ & $-24^{8.8}$ & $-\mathrm{I} 66$ & -6.9 & -166 & -6.9 & -38.0 & -64.8 \\
\hline $\begin{array}{l}\text { Sensible heat } \\
\text { flux }\end{array}$ & 3325 & 138.7 & I 907 & $79 \cdot 5$ & $9^{2}$ & 3.8 & 53 & 2.2 & 21.2 & 20.7 \\
\hline $\begin{array}{l}\text { Latent heat } \\
\text { flux }\end{array}$ & $4=8$ & 17.8 & 99 & $4 \cdot 1$ & 12 & 0.5 & 3 & 0.1 & 2.7 & I. I \\
\hline $\begin{array}{l}\text { Heat flux in } \\
\text { ice and snow }\end{array}$ & -585 & $-24 \cdot 4$ & -47 & -2.0 & $-\mathrm{I} 6$ & -0.7 & -1 & -0.04 & -3.7 & -0.5 \\
\hline Ablation & -9153 & $-3^{81} \cdot 7$ & $-3 \mathbf{r} 99$ & $-133 \cdot 4$ & -254 & -10.6 & -89 & -3.7 & $-5^{8} \cdot 3$ & $-34 \cdot 7$ \\
\hline
\end{tabular}




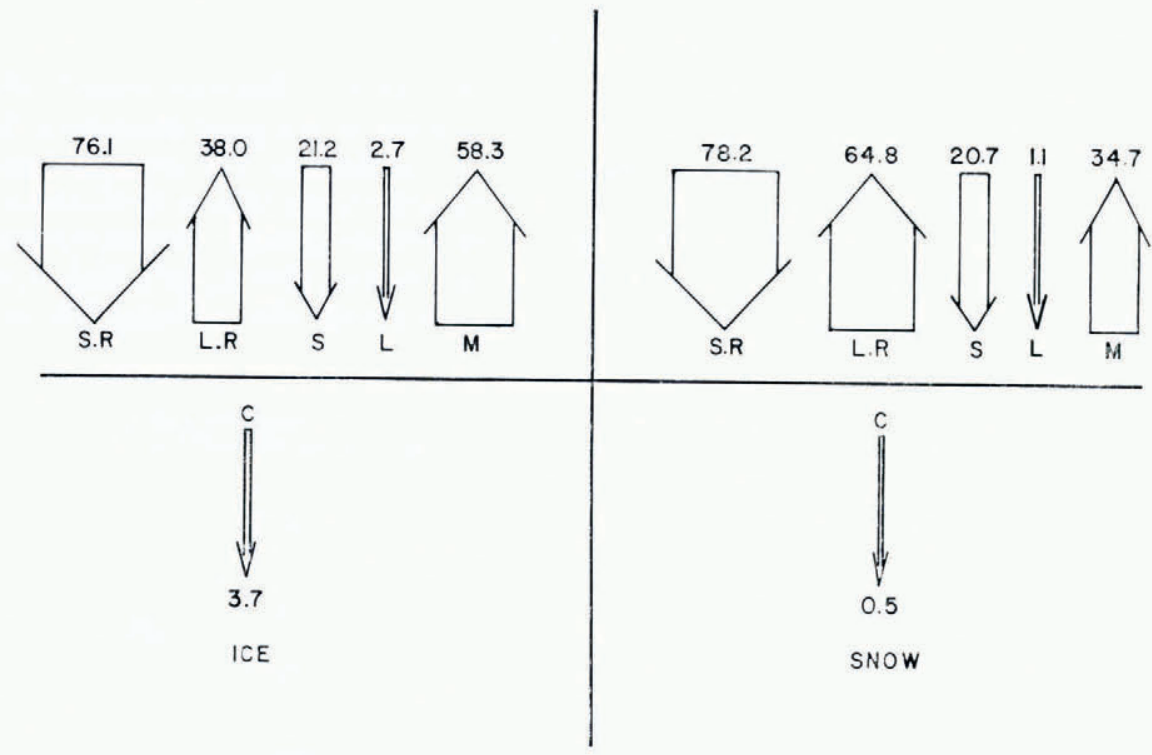

Fig. 9. Components of the heat balance over ice and snow in percent, McCall Glacier, I7 June-22 July I971. S.R. = shortwave radiation balance; $L . R .=$ long-wave radiation balance; $S=$ sensible heat flux; $L=$ latent heat flux; $M=$ energy used for melting; $C=$ heat flux by conduction.

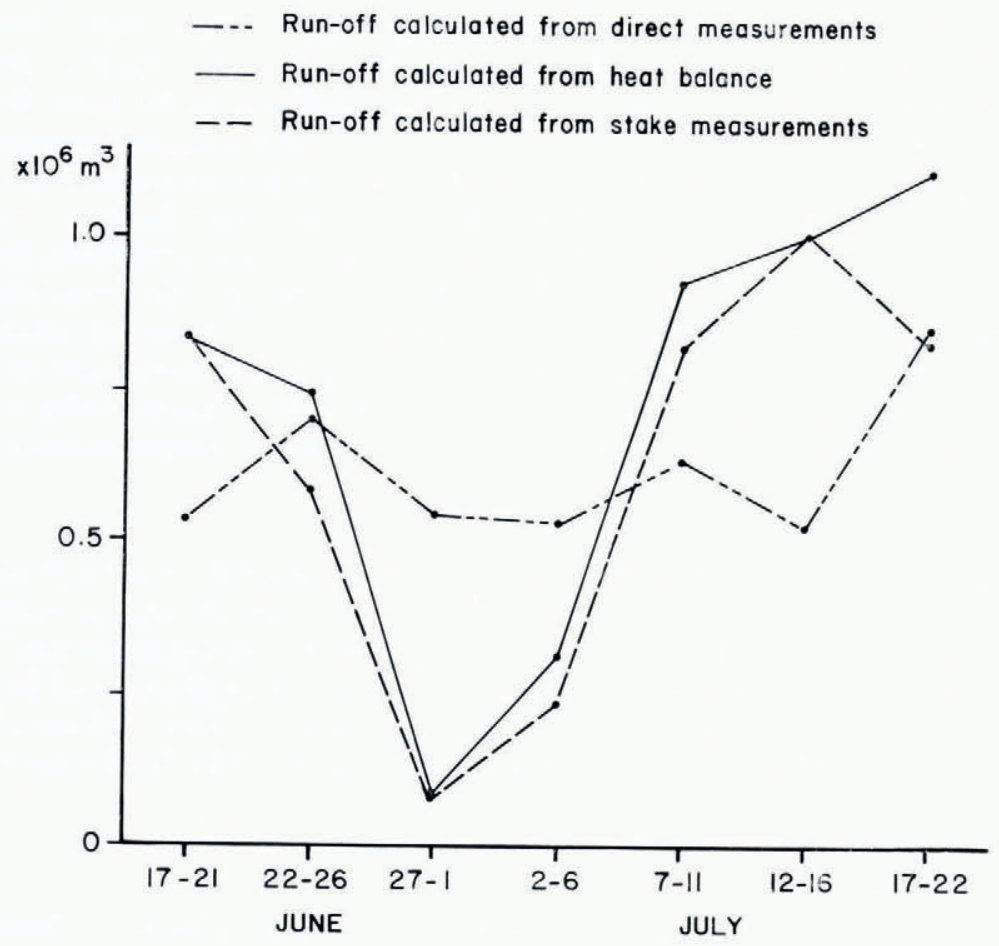

Fig. xo. Comparison of the amounts of discharge for five-day periods using direct, heat-balance and stake measurement. 


\section{The combined heat, ice AND WATER balance}

The combined heat, ice and water balance was calculated for five-day periods (Fig. Io). It can be seen, that ablation and heat-balance measurements show a good agreement for a five day period, but the direct run-off measurements are very different. The explanation for this is probably the liquid storage capacity of the McCall Glacier basin (Meier and others, I97 I).

In Table IX, the comparison is carried out for the whole period. Assuming the direct discharge measurement as correct, the heat balance calculations give a $5.5 \%$ higher, and the stake measurement an $8.9 \%$ lower value. Such an agreement can be regarded as totally satisfactory.

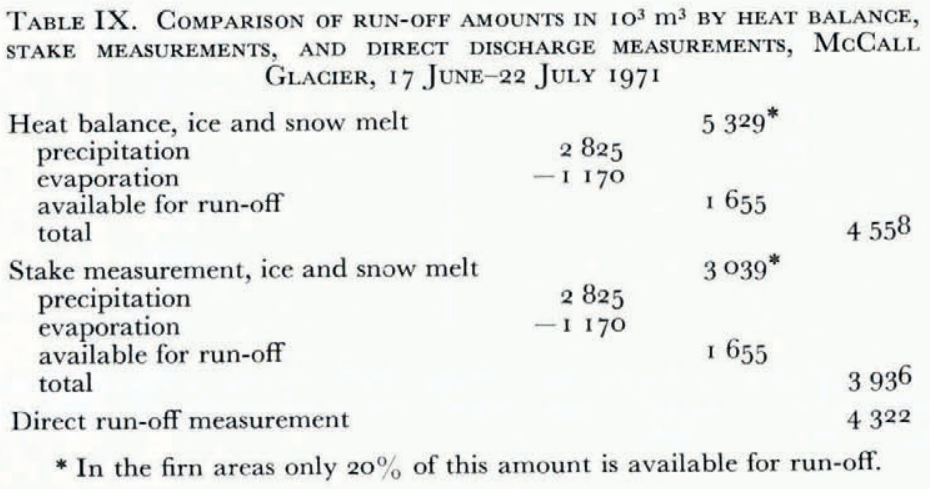

Analysis of the accuracy of this study is very difficult. Accumulation and ablation were estimated to be correct within $\pm 15 \%$ (Trabant and Fahl, in press), and a similar value is found for the discharge measurements (Wendler and others, in press). Further, some contributions to the discharge were due to the melt of the few remaining snow fields, the aufeis, and the ice covered moraines. This was not accounted for, as the amount was estimated to be relatively small as compared with the other contributions. The heat balance at the measured points is within $\pm 8 \%$ for radiation, and $10 \%$ for the eddy fluxes. Further, it relies on two assumptions: (a) no advection takes place and (b) the austausch coefficients for movement, sensible and latent heat flux are identical. It is difficult to estimate the error, which is caused by integrating the heat fluxes over the whole glacier surface. Thus no overall numerical estimate of accuracy is given and the reader may make a personal assessment of the extent to which the assumptions are realistic. However, the disagreement found in this study by using the three methods is within the accuracy estimated for different measurements.

\section{Conclusion}

It has been shown that the agreement between the combined heat, ice and water balances for the McCall Glacier during a $3^{6}$ day period in the summer of $197 \mathrm{I}$, is reasonably good. This result may further be taken as an indication, that the assumptions which had to be made, especially those for obtaining the heat balance for the whole glacier and for the evaporation over the bare area in the watershed, are reasonable. Furthermore, it shows, that the mass balance, at least of a cold glacier, can be calculated in each of the three ways with a similar result.

\section{Acknowledgements}

The research was supported by the Atmospheric Sciences Section, National Science Foundation, under Grants GA-28278x and GA-37306; logistic support was given by the Air 
National Guard. The authors thank their co-workers, notably Dr C. Benson, Dr C. Fahl, Mr J. Slivkoff, and Mr D. Trabant, who in part carried out the field measurements. Mrs T. McClung and Mrs J. Leap reduced the data, and Professor B. Holmgren and Professor N. Streten read the manuscript; their valuable comments improved this paper.

MS. received 25 September 1973

\section{REFERENCES}

Albrecht, F. 1940. Untersuchungen über den Wärmehaushalt der Erdoberfläche in verschiedenen Klimagebieten. Wissenschafiliche Abhandlungen, Reichsamt für Wetterdienst, Abh. 8, No. 2.

Derikx, A. L. In press. The energy balance and associated run-off from an experimental site on the glacier tongue. [Paper presented at the International Union of Geodesy and Geophysics, XV General Assembly, Moscow, 30 July-14 August 1971.]

Hoinkes, H. C. I953. Wärmeumsatz und Ablation auf Alpengletschern. II. Hornkees (Zillertaler Alpen), September 1951. Geografiska Annaler, Årg. 35, Ht. 2, p. 1 i6-40.

Hoinkes, H. C. 1955. Measurements of ablation and heat balance on Alpine glaciers. Fournal of Glaciology, Vol. 2, No. 17, p. 497-501.

Hoinkes, H. C. [ $\left.{ }^{\mathrm{c}} \mathrm{I} 964.\right]$ Glacial meteorology. (In Oc'ishaw, H., ed. Research in geophysics. Vol. 2. Solid earth and interface phenomena. Clambridge, Mass., Massachusetts Institute of Technology Press, p. 391-424.)

Hoinkes, H. C., and Wendler, G. 1968. Der Anteil der Strahlung an der Ablation von Hintereis- und Kesselwandferner (Ötztaler Alpen, Tirol) im Sommer 1958. Archiv für Meteorologie, Geophysik und Bisklimatologie, Ser. B, Bd. 16, Ht. 2-3, p. $195^{-2} 26$.

I.H.D. I966. International Hydrological Decade. Phase I. U.S. program. Report by U.S. National Committee for I.H.D. Washington, D.C., National Academy of Sciences, National Research Council, p. $3 \mathrm{O}^{-} 34$.

Kondratyev, K. Y. 1969. Radiation in the atmosphere. New York and London, Academic Press. (International Geophysics Series, Vol. 12.)

LaChapslle, E. R. 1959. Annual mass and energy exchange on the Blue Glacier. Fournal of Geophysical Research, Vol. 64 , No. 4 , p. $443-49$.

Lang, H. ${ }^{19} 58$. Relations between glacier runoff and meteorological factors observed on and outside the glacier. Union de Géodésie et Géophysique Intsrnationale. Asssciation Internationale d'Hydrologie Scientifique. Assemblée générale de Berne, 25 sept. $\rightarrow 7$ oct. 1967. [Commission de Neiges et Glaces.] Rapports et discussions, p. 429-39.

Lettau, H. 1939. Atmosphärische Turbulenz. Leipzig, Akademische Verlagsgesellschaft.

Lettau, H. 1949. Isotropic and non-isotropic turbulence in the atmospheric surface layer. Bedford, Mass., Geophysics Research Directorate, U.S. Air Force Cambridge Research Center. (Geophysical Research Papers, No. I.)

Meier, M. F., and others. I97I. Ice and water balances at selected glaciers in the United States. Combined ice and water balances of Gulkana and Wolverine glaciers, Alaska, and South Cascade Glacier, Washington, 1965 and 1966 hydrologic years, by M. F. Meier, W. V. Tangborn, L. R. Mayo, and A. [S.] Post. U.S. Geological Survey. Professional Paper 715-A.

Munn, K. E. 1966. Descriptive micrometeorology. Advances in Geophysics, Supplement I.

Orvig, S., ed. 1961. McCall Glacier, Alaska: meteorological observations, 1957-1958. Arctic Institute of North America. Research Paper No. 8.

Prandtl, L. 1956. Führer durch die Strömungslehre. 4. Auflage. Braunschweig, F. Vieweg und Sohn.

Searby, H. W. 1968. Cli nates of the States. Alaska. Washington, D. C., U.S. Weather Bureau. (Climatology of the United States, No. 6o-49.)

Streten, N. A., and Wendler, G. I968. The midsummer heat balance of an Alaskan maritime glacier. Journal of Glaciology, Vol. 7, No. 51, p. $43^{1-40 .}$

Trabant, D., and others. In press. Mass-balance and superimposed ice formation on McCall Glacier, Brooks Range, Alaska, 1971 and 1972 hydrologic years, by D. Trabant, C. Fahl and C. S. Benson. Fournal of Glaciology.

Turner, H. I961. Jahresgang und biologische Wirkungen der Sonnen- und Himmelsstrahlung an der Waldgrenze der Ötztaler Alpen. Wetter und Leben, Jahrg. 13, Ht. 5-6, p. 93-1 13 .

Wendler, G., and Ishikawa, N. I973[a]. Experimental study of the amount of ice melt using three different methods: a contribution to the International Hydrological Decade. Journal of Glaciology, Vol. 12, No. 66, p. 399-410.

Wendler, G., and Ishikawa, N. 1973[b]. Heat balance investigation in an Arctic mountainous area in northern Alaska. Journal of Applied Meteorology, Vol. 12, No. 6, p. 955-62.

Wendler, G., and Ishikawa, N. 1974. The effect of slope, exposure and mountain screening on the solar radiation of McCall Glacier, Alaska: a contribution to the International Hydrological Decade. Fournal of Glaciology, Vol. 13, No. 68, p. 21 $3-26$.

Wendler, G., and Weller, G. 1974. A heat-balance study on McCall Glacier, Brooks Range, Alaska: a contribution to the International Hydrological Decade. Journal of Glaciology, Vol. I3, No. 67, p. I $3-26$.

Wendler, G., and others. In press. On the hydrology of a partly glacier-covered Arctic watershed, by G. Wendler, D. Trabant, and C. [S.] Benson. [Paper presented at International Symposia on the Role of Snow and Ice in Hydrology, Banff, Canada, UNESCO Session 4, 8 September 1972.] 